\title{
Geotourism, Iconic Landforms and Island-Style Speciation Patterns in National Parks of East Africa
}

\author{
Roger N. Scoon ${ }^{1}$
}

Received: 24 May 2019 / Accepted: 10 June 2020 / Published online: 9 July 2020

(C) The Author(s) 2020

\begin{abstract}
Many of the national parks in East Africa are equally as famous for their iconic landforms as they are for their diversity and concentrations of fauna and flora. The newly formed Ngorongoro-Lengai Geopark in northern Tanzania is the first geopark to be established in the region, but there is remarkable potential for geotourism in the majority of the national parks. The most spectacular landforms have been shaped by the East African Rift System. Formation of the two major rifts in the region, the Albertine Rift (or western branch) and the Gregory Rift (or eastern branch), was accompanied, or in some cases preceded, by extensive alkaline volcanism. The rifting and volcanism are primarily Late Cenozoic phenomenon that dissected and overprinted the older regional plateaus. Rifting impacted the regional drainage and captured major rivers, including the Victoria Nile. Chains of ribbon lakes formed in the rift valleys. The Albertine Rift consists of a sequence of sedimentary basins with deep freshwater lakes, but the shallow soda lakes of the Gregory Rift are associated with mostly volcanic terrains. Plateau-style volcanic outpourings smoothed out the older land surfaces, created near-lunar landscapes in parts of the rift valley, and built up rift shoulders to tremendous elevations. Magma erupted from central conduits formed giant stratovolcanoes which reveal evidence of explosive, Plinian-style volcanic activity. East Africa includes some of the largest and best preserved calderas on Earth. The Ngorongoro Caldera is a world heritage site. The ice-capped peaks of the two largest volcanoes in the region, Kilimanjaro and Mount Kenya, are among the highest free-standing mountains on Earth. The region includes active volcanoes, several of which are potentially hazardous as they are located near urban centres. Examples include Longonot-Hells Gate (Kenya), Mount Meru (Tanzania) and Nyiragongo (Democratic Republic of Congo). East Africa is renowned for the unusual rapidity of Darwinian evolution during the past thirty million years, including evolution of primates and hominins, and it is not a coincidence that significant palaeoanthropological discoveries have been unearthed from the Oldupai Gorge and Laetoli sites in northern Tanzania. The evolutionary period coincides with the onset and persistence of rifting and volcanism. Speciation is following an island-style pattern in East Africa, despite the continental setting, as regional plateaus are being dissected by the ongoing rifting and volcanism into smaller and smaller geological terrains. This is illustrated by restriction of the endangered Mountain gorilla to regions where afromontane forests developed in rift-related uplands isolated by extensive savannah grasslands.
\end{abstract}

Keywords East African Rift · Geoparks · Geotourism · National Parks · Regional plateau · Speciation · Volcanism

\section{Introduction}

Many of the national parks and conservation areas of East Africa are famed for their great concentrations and diversity of fauna and flora (e.g. Williams et al. 1994). These areas also reveal iconic landforms, including for example rift valleys

Roger N. Scoon

rnscoon@iafrica.com

1 Department of Geology, Rhodes University, Grahamstown, South Africa constrained by regional escarpments, large calderas and giant free-standing volcanic cones (Fig. 1). The interior of East Africa is characterized by two broad geomorphological terrains. Regional plateaus formed due to a period of almost continental-scale uplift and erosion in the Late MesozoicEarly Cenozoic. The plateaus were subsequently dissected by the East African Rift System (EARS). The EARS is primarily a Late Cenozoic phenomenon. Rifting was accompanied, or in some cases preceded, by extensive alkaline volcanism, a characteristic of continental rifting (Bailey 1974). The volcanism is in part manifested by catastrophic, Plinian-style eruptive activity and there are a number of active and 
Fig. 1 a Western Escarpment of the Gregory Rift, Lake Natron is comprised of multiple, nearhorizontal layers of lava and ash (horizontal striations) with braided drainage indicative of the recently-formed rift valley. $\mathbf{b}$ Rugged, central peaks of the extinct Mount Kenya Volcano are associated with an intrusive body which blocked the conduit. c Kibo, the highest volcano of the Kilimanjaro massif viewed from Mount Meru includes relicts of slope glaciers. $\mathbf{d}$ The Ash Cone in the caldera of Mount Meru, Arusha National Park is rimmed by historical lava flows. e The Shaitani lava flow with a central ridge and cinder-dominated flanks was erupted in 1865/6 from a cinder cone in the Chyulu Hills (back right). f Hominin fossils at Oldupai Gorge have been found in clays and volcanic tuffs of Beds I and II (divided by the Marker Tuff) and the red sands (Bed III) which cap the cliffs, as well as the underlying Naabi Ignimbrite (associated with the 2 Ma-old caldera-event of the Ngorongoro Volcano), contain either few or no fossils
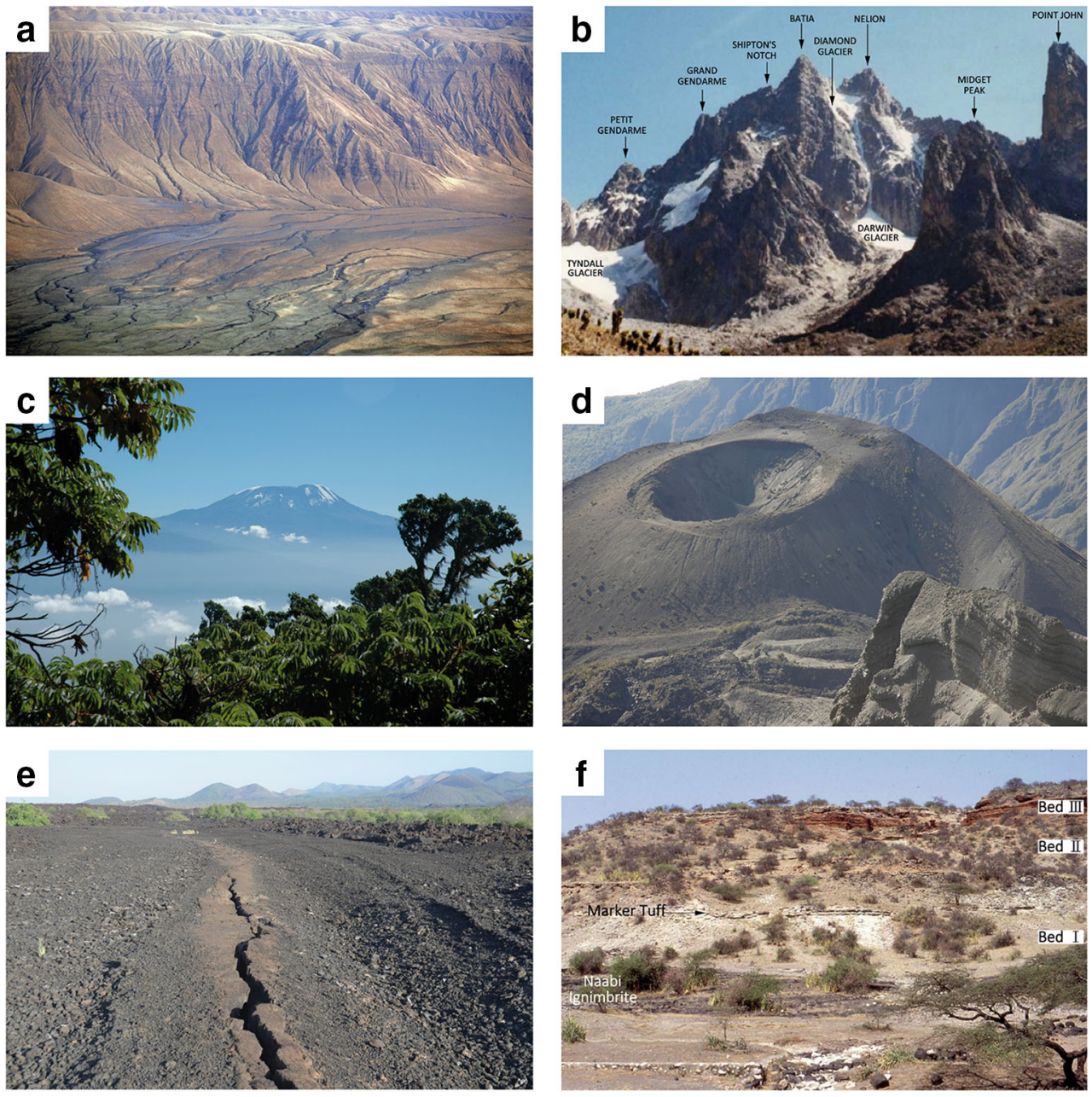

potentially hazardous volcanoes in the region (Baker et al. 1972; Dawson 2008).

The contrast between regional plateaus underlain by some of the oldest rocks on Earth and the relatively youthful and active EARS is an unusual feature of the region. Regional plateaus continue to be dissected into smaller and smaller geological terrains. The relationship between the unusual geology and the rapid Darwinian evolution for which the region is renowned has been widely debated (Nicholson 1996a; Thompson et al. 2002; Demencal 2004). Rifting and volcanism during the previous $30 \mathrm{Ma}$ influenced evolution of primates and hominins in the region (e.g. Leakey 1984; Cerling et al. 2011). The influence of the active geological systems on patterns of speciation is further described here. A brief overview of the regional geology is included with emphasis attached to the extensiveness of the East African volcanic province.

\section{Geoparks}

East Africa has considerable potential for establishment of geoparks, i.e. unified areas that advance the protection and use of geological heritage in a sustainable way, and promote the economic well-being of the people who live in the region (Wikipedia). In many cases, geoparks could be combined with existing national parks and would not necessarily require additional areas to be afforded protective status. The national parks described here occur in parts of five countries: northern Tanzania, central/southern Kenya, southern Uganda, northern Rwanda and the Goma district in the eastern part of the Democratic Republic of Congo (DRC) (Fig. 2). Examples of the close relationship between the geology and distribution of fauna and flora include the following well-known localities. The Ngorongoro caldera is a world heritage site included in the newly formed Ngorongoro-Lengai Geopark, the first geopark to be established in the region. The Ngorongoro Caldera includes a diversity of ecosystems constrained by the mostly intact internal walls. The migration of grazers on the eastern Serengeti Plains is in part controlled by the occurrence of nutrient-rich short grasses associated with eruptions of calcaerous ahs from the active Oldoinyo Lengai Volcano. Soda lakes of the Gregory Rift reveal a remarkable diversity of birds, including the flamingo which have adapted to the toxic environment. Afromontane forests of the Aberdare Hills and 


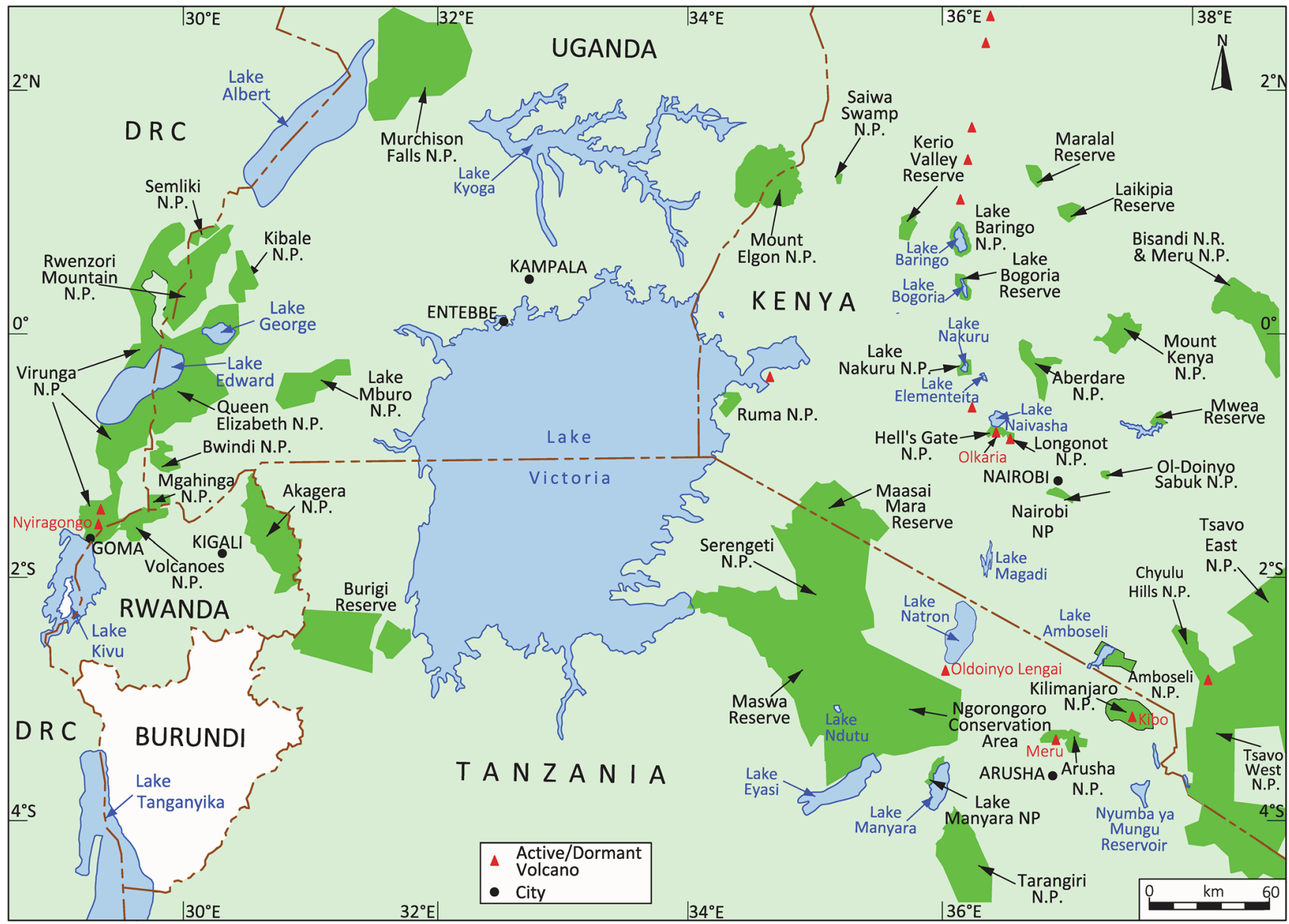

Fig. 2 Map showing the location of national parks and conservation areas in part of East Africa

the lower slopes of Mount Kenya are specialized habitats of melanistic variants of large cats. Forests associated with riftrelated uplands on the Bwindi massif and Virunga Mountains are the only habitats of the endangered Mountain gorilla. Alpine moorlands situated on the giant, free-standing mountains contain endemic plants.

\section{Regional Geology}

The earliest geologists to traverse East Africa, including Joseph Thomson (Thomson 1880), commemorated by, for example, Thomson's gazelle (Eudorcas thomsonii) and Thomson's Falls (Nyahururu), and John Walter Gregory (Gregory 1896) for whom the eastern branch of the rift valley is named after, recognized two broad geomorphological and geological terrains: (i) regional plateaus underlain by ancient, crystalline metamorphic rocks; and (ii) the narrow rift valleys, uplifted rift shoulders and giant volcanic edifices associated with the EARS. The unusual occurrence of ribbon lakes within the heart of the continent (Fig. 3) was reconciled by Suess (1885-1901) as indicative of the presence of "grabens", i.e. linear valleys formed by displacement of blocks of land downward. Grabens form by stretching and thinning of the crust (rifting). The ability of lithospheric plates to drift, collide and stretch is widely accepted (Wilson 1973; Windley 1977). Rifting is probably initiated by major thermal events (e.g. Merle 2011). A key component of the hypothesis of continental drift is the concentration of seismic activity and volcanism on plate boundaries. The linear alignment of these phenomena in the interior of East Africa is an anomalous feature of the African Plate (Nusbaum et al. 1993) (Fig. 4). A geological map shows the distribution of basement complexes in areas not overlain by younger systems associated with the EARS, together with the relationship between the Ethiopian Rift and the Albertine and Gregory Rifts (Fig. 5).

\section{Basement Complexes}

The Basement Complexes of East Africa encompass two billion years of the Archaean and Proterozoic eras (Begg et al. 2009; Dirks et al. 2015), i.e. prior to the appearance of hardshelled animals at the beginning of the Phanerozoic. The oldest component is the Central African Craton (2.8- 





Fig. 3 A satellite image of East Africa reveals the three principal branches of the East Africa Rift System and their chains of ribbonshaped lakes. Source: Cloud-free composite image based on TerraMODIS satellite images of NASA

2.5 Ga). This stable, deep-keeled block is comprised of overlapping granite-gneiss plutons and greenstones that outcrop over large parts of central/southern Kenya (Fig. 6), northern Tanzania (Fig. 7) and southern Uganda (Fig. 8). The granitegneiss may form distinctive "koppies" or small head-shaped hills, e.g. on the Serengeti Plains. The craton is enclosed by two Palaeoproterozoic mobile belts (high-grade metamorphic rocks), the Usagaran and Ubendian $(2.2-2.1 \mathrm{Ga})$. The Rwenzori Mountains are an unusual example of a horst block comprised of basement terrains located within the rift valley. The intracratonic Kibaran Belt (1.7-1.4 Ga) is a thick unit of Mesoproterozoic sedimentary rocks restricted to southern Uganda and northern Tanzania. The Mozambique Belt (0.8 $0.5 \mathrm{Ga}$ ) is a Neoproterozoic (and possibly Lower Cambrian) mobile belt primarily located east of the Central African Craton. This system is exposed in the eastern Serengeti Plains (Oldupai Gorge) and on the Tsavo Plains.

\section{Gondwana Uplift and Erosion}

Break-up of Gondwana, the ancient supercontinent resulting from accretion of the southern landmasses of Pangaea during the Neoproterozoic-Palaeozoic, was a long-drawn out process which commenced in the Jurassic-Cretaceous periods and extended into the Early Cenozoic (180-35 Ma) (e.g. Dirks et al. 2015). This included opening of the Atlantic and Indian Oceans and the isolation of the African Plate. Rifting on the margins of the plate was initiated by a mantle plume. Partial melting of the lithopshere and under-plating of the Crust caused almost continental-scale uplift. Uplift triggered intense cycles of erosion, enhanced by the tropical climate of the Late Mesozoic and Early Cenozoic. Regional plateaus in East Africa are mainly associated with the 70 Ma-old African Erosion Surface (Saggerson and Baker 1965). They are underlain by ancient crystalline metamorphic rocks and the paucity of Palaeozoic-Mesozoic rocks is a notable feature of East Africa.

\section{East African Rift System}

The EARS is represented by two branches in the region of East Africa described here: the Albertine Rift (western branch) and the Gregory Rift (eastern branch) (Fig. 3). The Albertine Rift extends southward as far as Mozambique, but the Gregory Rift peters out in northern Tanzania. The linkage between the Albertine/Gregory Rifts and the Ethiopian Rift has been widely debated (e.g. Ebinger et al. 2000). The latter extends northward into the Middle East and includes a triple
Fig. 4 Major seismic events and active volcanoes in the interior of the African Plate are associated with the East African Rift System

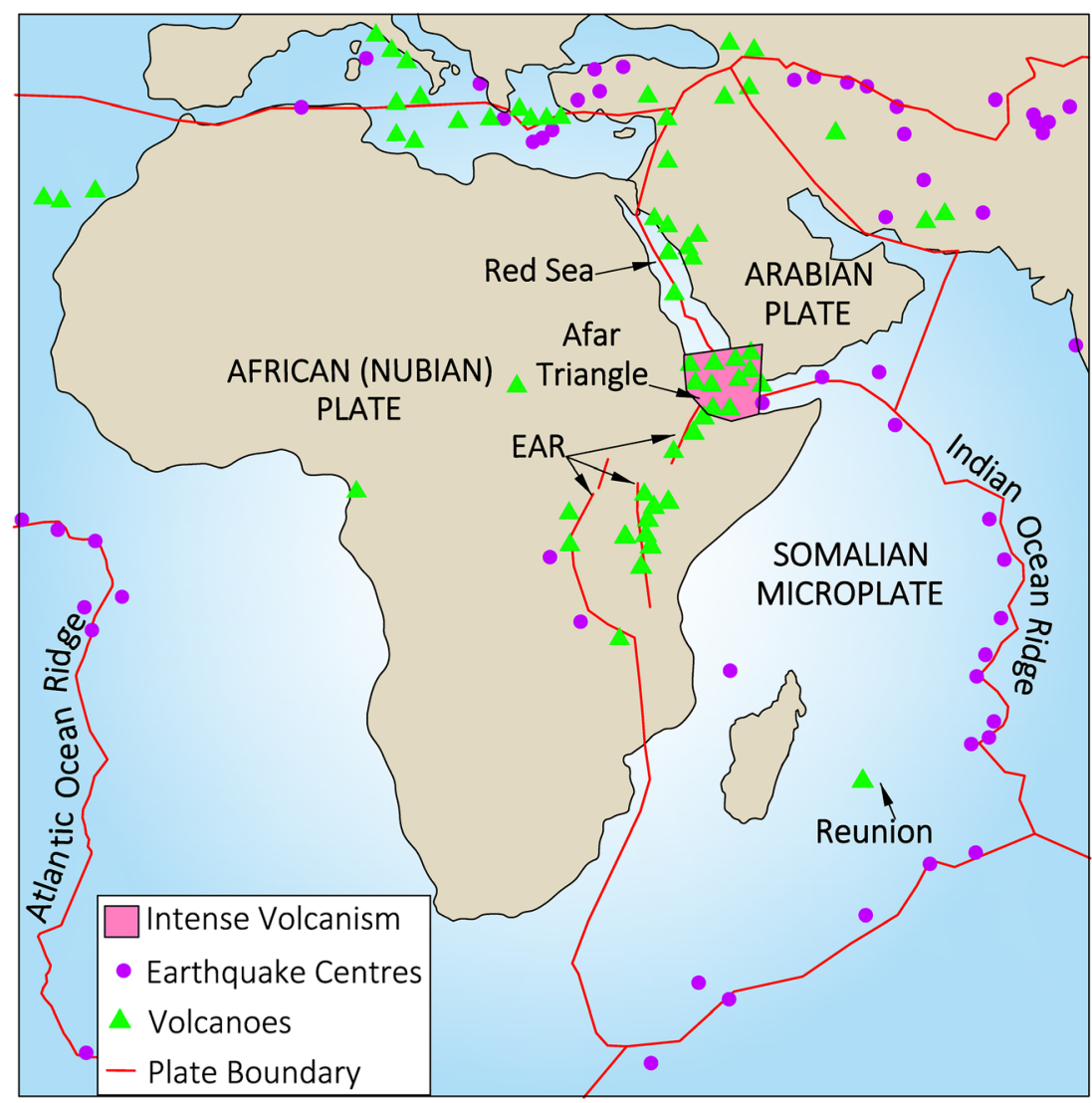







Fig. 5 A simplified regional geological map shows the extensiveness of basement terrains in the regional plateaus between the rift valleys and the dominance of volcanic terrains in the Ethiopian Rift and Gregory Rift

junction with the Red Sea Rift and the Gulf of Aden which has brought oceanic crust close to surface (Fig. 5). This suggests that the African continent could at some stage separate into a Nubian Plate and a Somalian Microplate (Fig. 4) (Sarie et al. 2014; Ebinger 2005).

Rifting and volcanism in the EARS was initiated in the Oligocene epoch at approximately $30 \mathrm{Ma}$, but the peak occurred in the Miocene, Pliocene and Pleistocene epochs (Chorowicz 2005; Baker and Wohlenberg 1971). The Ethiopian Dome and Kenyan-Tanzanian Dome are regional expressions of volcanicrelated uplift which preceded the main development of faults (Fig. 5). The volcanism of the EARS is associated with a mantle plume, possibly a rejuvenation of the Gondwana plume (Sarie et al. 2014). The intensity of volcanism in several sections of the rift (e.g. the Afar Triangle in Ethiopia; the Northern Tanzanian Divergence: Fig. 5) has promoted a view that continental rifts are driven by volcanism rather than plate movements. The rift valleys of East Africa could, therefore, have developed from crustal doming rather than lithospheric stretching and thinning. This explanation is consistent with why the rift valleys occur above sea level, but the aforementioned triple junction and occurrence of shallow oceanic crust is indicative of rifting irrespective of volcanism (e.g. McKenzie 1978).

The crustal tectonism associated with the EARS defines three stages. An early-stage of pre-rift activity is restricted to regional warping. This is followed by a half-graben stage with linear depressions constrained by faults on one side. Formation of down-faulted blocks constrained by faults on either side represents the full graben stage, e.g. in the vicinity of Lake Nakuru, Kenya (Fig. 6b). The half-grabens and full grabens are characterized by normal faults which extend for several tens of kilometres. The surface expression of faults is escarpments, which in the EARS may reveal differential heights of several thousands of metres. Most escarpments in the Gregory Rift consist of multiple layers of volcanic lavas and ashes (Fig. 1a).

Both the Albertine Rift and the Gregory Rift are propagating southward. The Gregory Rift has a lateral extension of approximately $8 \mathrm{~km}$ and is almost entirely infilled by volcanic deposits (Fig. 6). The deep-rooted Central African Craton has caused the Gregory Rift to refract eastward in northern Tanzania (Ebinger et al. 1997; Le Gall et al. 2008). The less resistant Mozambique Belt has proved more amenable to rift. The Northern Tanzanian Divergence is an area of intense volcanism which includes three branches (Fig. 7). The NatronManyara Rift and Eyasi Rift are half-grabens (they peter out southward), and the Pangani Rift is a full graben which extends toward the Indian Ocean (Fig. 3). The Albertine Rift reveals a lateral extension of approximately $30 \mathrm{~km}$. This rift is dominated by juxtaposed sedimentary basins within halfgrabens (Fig. 8) (Maasha 1975).

\section{East African Volcanic Province}

Magma associated with the rifting was erupted in two discrete styles (Baker et al. 1972; Barberi et al. 1982; Dawson 2008; Woolley 2001). Plateau-style outpourings smoothed out palaeo-land surfaces, partially infilled rift valleys, and uplifted rift shoulders. Some sections of the Gregory Rift, e.g. in the vicinity of Lake Bogoria, are entirely volcanic and exhibit a near-lunar landscape. Shoulders of the Gregory Rift constitute extensive uplands, e.g. the Aberdare Hills. Secondly, magma was erupted from long-lived conduits, which resulted in formation of large edifices and giant stratovolcanoes. Many of the conduit-related volcanic cones reveal evidence of explosive, Plinian-style activity, including formation of large calderas and widespread fallout of radioactive ash.

The composition of magmas associated with the plateaustyle outpourings in the Gregory Rift follows a relatively welldefined trend (Baker 1987). The pre-rift activity involved nephelinite-phonolite magmas, the half-graben stage saw a switch to alkaline basalt-phonolite magmas and the full graben stage transitional basalt-rhyolite magmas (Fig. 9a, b). The stratovolcanoes and discrete cones follow a somewhat less well-defined trend, although Mount Elgon (height of $4321 \mathrm{~m}$ ), probably the oldest of the giant cones (age of $22 \mathrm{Ma}$ ), consists largely of nephelinite ashes (Simonetti and Bell 1995). Elgon is one of the few manifestations of the prerift cones as most of these features have either been eroded or covered by younger eruptions. The Ngorongoro Caldera (2 Ma) is part of a large, multi-centred Pliocene-age volcanic complex-the Ngorongoro Volcanic Complex (1.8$3.5 \mathrm{Ma}$ - - located in the Eyasi half-graben (Dawson 2008). The complex is dominated by eruptions of alkaline basalt and phonolite magmas (Mollel et al. 2008), typical of the half-graben stage of rifting. Volcanic centres consisting of transitional basalt and rhyolite, i.e. associated with the full graben stage, are found in central Kenya. Mount Longonot is an active cone located within a much larger (and older) caldera in the floor of the Gregory Rift near Lake Naivasha (Scott 1980) (Fig. 6a). The Olkaria Complex (Woolley 2001), the principal geological feature of the Hell's Gate National Park, overlies a shallow magma chamber which is a major source of geothermal energy. The Njorowa Gorge exposes a finely bedded sequence of Upper Pleistocene-Holocene rhyolite lavas and ashes associated with the Olkaria Complex (Fig. 10). Clusters of volcanic explosion craters in the Albertine Rift are exposed in the Queen Elizabeth National Park, Uganda (Fig. 8). The explosion craters are associated with potassic-rich alkaline magmas that contain a suite of unusual minerals (Woolley 2001). 
The eastern shoulder of the Gregory Rift contains some of the highest and largest free-standing mountains on Earth. Mount Kenya $(5199 \mathrm{~m})$ is a Pliocene-age cone (4.5-2.6 Ma) with a basal circumference of more than $150 \mathrm{~km}$. The rugged nature of the central peaks (Fig. 1b) is related to an intrusive body of syenite which terminated the activity by blocking the central conduit (Baker 1987). Two of the three volcanoes that make up the Kilimanjaro massif, Shira (2.5-1.9 Ma) and Mawenzi (1.0-0.45 Ma), are extinct, but the Kibo Caldera (0.48-0.15 Ma), which includes Uhuru Peak (5895 m) on the southwestern rim, is capped by a dormant summit crater (Downie and Wilkinson 1972) (Fig. 1c). Mount Meru (4565 m) is a giant cone disrupted by a caldera which is open on the east side (Fig. 11). This is ascribed to partial collapse of the main cone, which occurred at approximately 8000 BP. The formation of the Meru Caldera triggered one of the world's largest debris avalanche deposits (this feature extends $35 \mathrm{~km}$ eastward as far as the lower slopes of Kibo) (Delcamp et al. 2015). The caldera contains a large ash cone, last active in 1910 (Fig. 1d).

The Chyulu Hills in southeastern Kenya is a young volcanic range (Woolley 2001) which includes dormant cinder cones and lava flows that extend into the Tsavo West National Park (Fig. 1e). The most recent eruption is estimated to have occurred in 1865/6. Oldoinyo Lengai in the Gregory Rift near Lake Natron is famous for bimodal eruptions of silicate (nephelinite) and natrocarbonatite magmas. This is the only active volcano of this type on Earth and has been widely studied (Dawson et al. 1995; Dawson 2008; Dawson and Mitchell 2008).

The Virunga Mountains is a volcanic range located partially in northern Rwanda and eastern DRC which also overlaps into southern Uganda (Fig. 2). The maximum age of the volcanism is estimated at $0.1 \mathrm{Ma}$ (Woolley 2001). The most persistently active cone is the Nyiragongo Volcano (3470 m) which consists of a central cone with a 250-400-m-deep summit crater. The crater has a diameter of approximately $2 \mathrm{~km}$, is enclosed by near-vertical sidewalls and contains an active lava lake and vent (Fig. 12a, b). Nyiragongo can extrude anomalously fastmoving lava flows associated with the potassium-rich alkaline magmas (Tedesco et al. 2007; Wauthier et al. 2012).

Oldoinyo Lengai erupts on average every $10-15$ years and is the most active volcano in the EARS. Meru invites comparisons with the catastrophic eruption of volcanoes such as Mount St. Helens in Washington State. The Longonot Volcano and the Olkaria Complex are comparable with the Yellowstone Supervolcano in Wyoming. Nyiragongo is one of the world's most active volcanoes and is situated approximately $20 \mathrm{~km}$ from the regional centre of Goma.

\section{Geomorphology and Drainage Patterns}

Landforms associated with the Gregory Rift have resulted in a great diversity of ecosystems, in part due to the remarkable
Fig. 6 a Geological map of central and southern Kenya compiled from various sources including the 1:1000,000 scale map of the Ministry of Energy and Regional Development of Kenya (1987 Edition) and with some updates and changes. b Geological section of central Kenya based on Lake Nakuru (latitude $0^{\circ} 21^{\prime}$ South) extending from the Kisumu Gulf (Lake Victoria) to the eastern slopes of Mount Kenya. The thickness of the volcanics associated with the Gregory Rift is schematic. The youngest (Holocene) volcanics are restricted to the centre of the Rift Valley with the older (Miocene and Pliocene) volcanics located on the rift platforms. The Mount Kenya Volcanics are associated with a long-lived conduitstyle eruption on rift platform. Pleistocene age volcanics are missing from this section

altitudinal differences (Fig. 13). Most of the regional plateaus (elevations of 1200-1500 m) are associated with grassy and bushy savannahs. The narrow coastal plains are divided from interior plateaus by a regional escarpment that impacted major rivers. The absence of navigable rivers, which could have facilitated exploration of East Africa, can be ascribed to Gondwana-related uplift, albeit most rivers flow away from the rift valleys as the shoulders are tilted outward. The rift valleys (height of 500-1000 m) are relatively hot and arid. Large parts of the elevated rift shoulders (2000-3500 m) are densely forested as they report a temperate climate despite the equatorial setting. Free-standing mountains associated with the Gregory Rift, including Kilimanjaro and Mounts Kenya, Meru and Elgon, reveal annular botanical zones of afromontane and bamboo forests (up to $3000 \mathrm{~m}$ ) and alpine heath- and moorlands (up to $4500 \mathrm{~m}$ ). The latter report a high degree of endemism, and include species such as giant groundsels (Senecio brassica, Senecio keniodendron) and tree lobelias (Lobelia keniensis, Lobelia telekii).

Most lakes in the Gregory Rift (although not all) are shallow and alkaline with restricted (internal) catchment and high levels of evaporation (e.g. Eugster 1980). The anomalously high sodium contents and extreme alkalinity ( $\mathrm{pH}$ locally $>12$ ) are enhanced by erosion of the juxtaposed volcanic terrains (which include sodium-rich alkaline volcanic deposits). Many of the large and deep freshwater lakes in the Albertine Rift are palaeo-stratified and levels are persistently dropping (Nicholson 1996b).

Prior to rifting, rivers in the central part of East Africa flowed towards the Atlantic Ocean. The initial stage of rifting resulted in formation of an area of internal drainage due to uplift on the western flanks of the Albertine Rift (Fig. 14a) (Beadle 1981). As more and more rivers were captured, a giant palaeo-lake known as Lake Obweruka formed (Fig. 14b). The opening of the Beni Gap enabled rivers to resume the westward outlet (Fig. 14c), although this was a short-lived phenomenon due to repeated uplift and formation of the shallow Lake Victoria in a warp between the rift valleys (Fig. 14d) (Talbot and Williams 2008). During the peak of rifting, the main outlet of the Nile was the Katonga River (via the Albertine Rift). This system reversed with a watershed developing east of the Kazinga Channel in the Queen Elizabeth National Park (Fig. 14e). The 
a

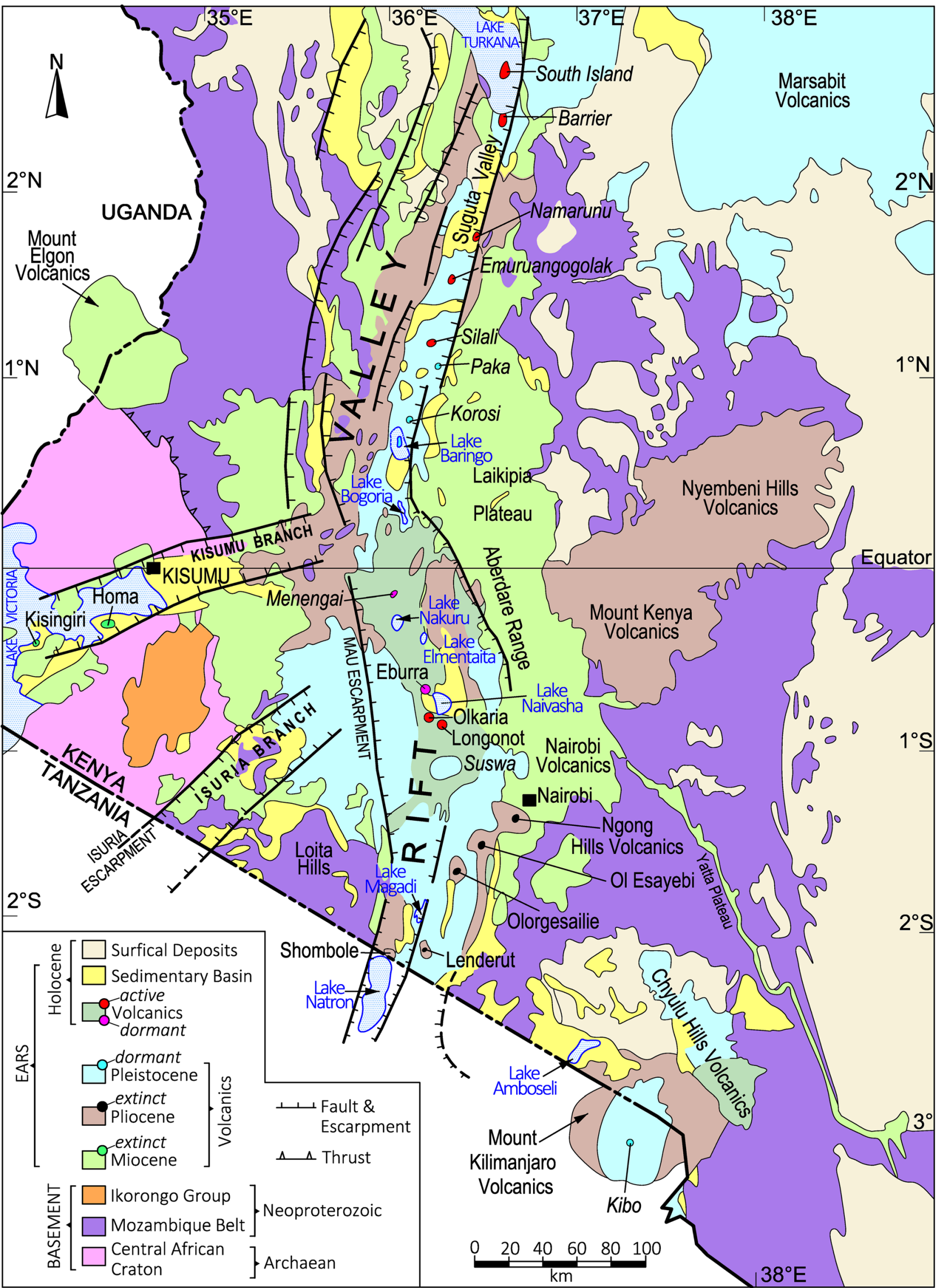




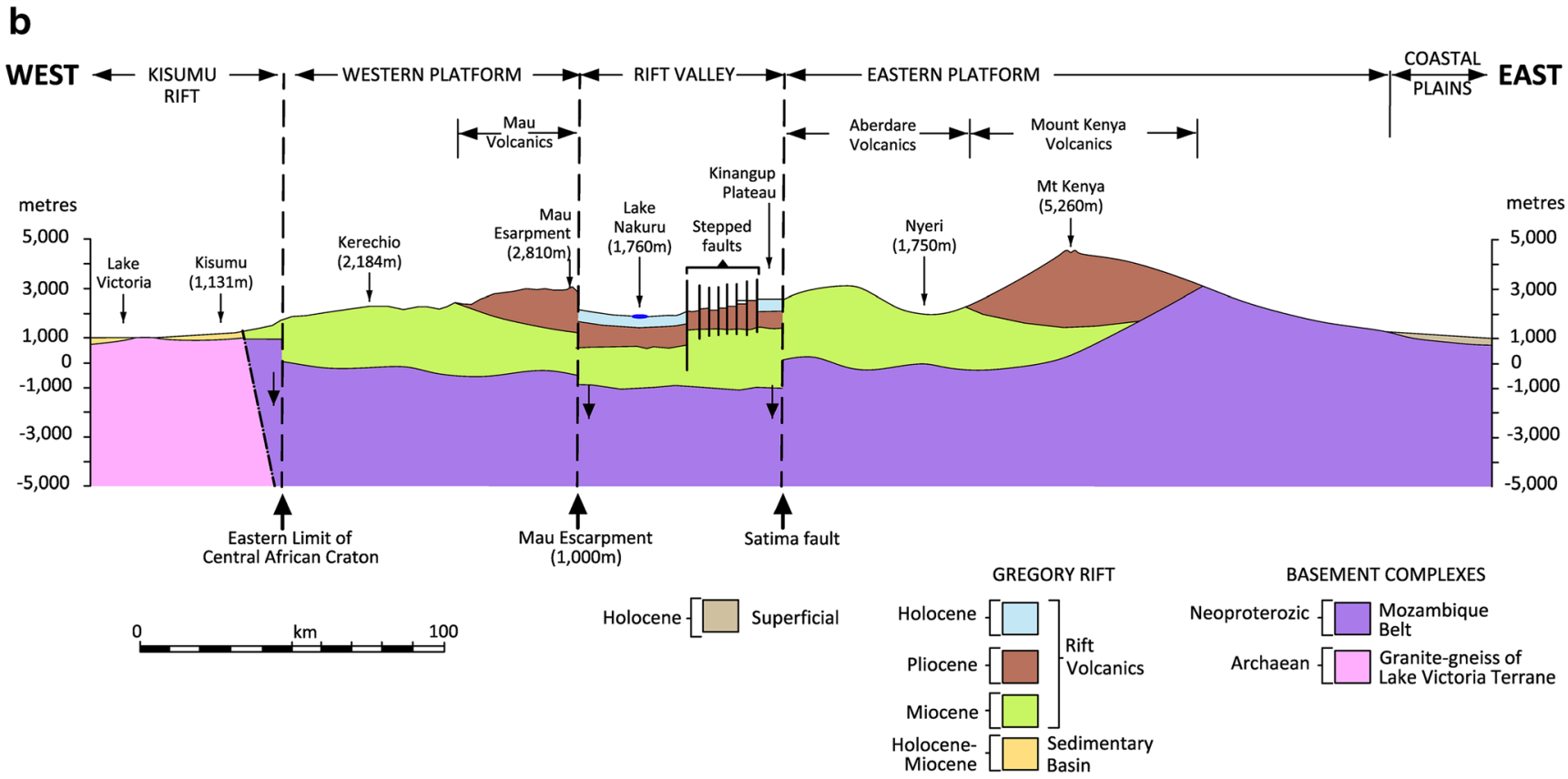

Fig. 6 (continued)

occurrence of rapids on the upper reaches of the Victoria Nile illustrates the youthfulness of the current channel (Fig. 14f). Murchison Falls is located where the Victoria Nile intersects the eastern edge of the Albertine Rift; headward erosion has been slowed by the crystalline basement.

\section{Hominins and Sedimentary Basins}

Sedimentary basins that developed in warps on the rift shoulders are persistently being reshaped by faulting and erosion of adjacent scarps. Basins proximal to the Gregory Rift are partially infilled by volcanic ash and volcaniclastics, in addition to clays and sands. Hominin fossils are preferentially preserved in basins containing water-lain volcanic ashes (tuffs). The palaeoanthropological sites of Oldupai Gorge (formerly known as Olduvai Gorge) and Laetoli on the eastern Serengeti Plains (part of the Ngorongoro Conservation Area) are associated with shallow indentations (ravines and areas of badlands erosion) in the regional plateau (Fig. 7). Hominin fossils and Oldowan stone tools discovered from these sites have greatly enhanced our understanding of human evolution (Leakey 1984). The basins are infilled by Plio-Pleistocene lacustrine sediments and volcanic ashes (Hay 1976; Blumenschine et al. 2012). The sequence at Oldupai Gorge is subdivided into seven formations, or beds, with many of the significant hominin fossils having been obtained from Beds I and II (Fig. 1f), e.g. the first discoveries of Zinjanthropus boisei (OH-5 dated at $1.848 \mathrm{Ma}$ ) and Homo habilis $(\mathrm{OH}-7$ dated at 1.848-1.832 Ma). The occurrence of marker layers of resistant tuff has enabled precise radiometric dating of the sequences to be obtained (e.g. Leakey 1984; Deino 2012). Fossils OH-5 and OH-7 were partially preserved in ash from the Ngorongoro Volcano (McHenry et al. 2008). The 27-mlong trail of footprints at Laetoli is related to Australopithecus afarensis (dated at 3.6 Ma) (Leakey 1981). The footprints occur in ash from the Sadiman Volcano (Zaitsev et al. 2011).

\section{Climatic Cycles}

The hot and humid climates of the Pliocene and Lower/Mid Pleistocene (Nicholson 1996b) were displaced by colder and drier conditions with onset of the Late Pleistocene Ice Ages (800,000-12,000 BP). Extensive icefields and slope glaciers developed on the higher peaks in East Africa. Desiccation events caused periodic drying of many lakes, including Lake Victoria (Johnson et al. 1996). The Pleistocene ice probably disappeared from the peaks at approximately $12,000 \mathrm{BP}$, prior to reforming at the onset of the Holocene, i.e. 11,700 BP (Osmaston 2004). The Ice Ages were superseded in the Early Holocene by the African Humid Period (11,700-5000 BP), a hot and wet phase interrupted by an intensely dry phase at $8300 \mathrm{BP}$. The Mid Holocene included a dry phase known to historians as the First Dark Age (4000-3700 BP) as it impacted civilizations in North Africa and the Middle East. Soda lakes of the Gregory Rift were transformed into large, freshwater palaeo-lakes during wetter times of the Early/Mid Holocene, but became alkaline and desiccated during the drier periods at $8300 \mathrm{BP}$ and 4000-3700 BP. Since $3700 \mathrm{BP}$, 


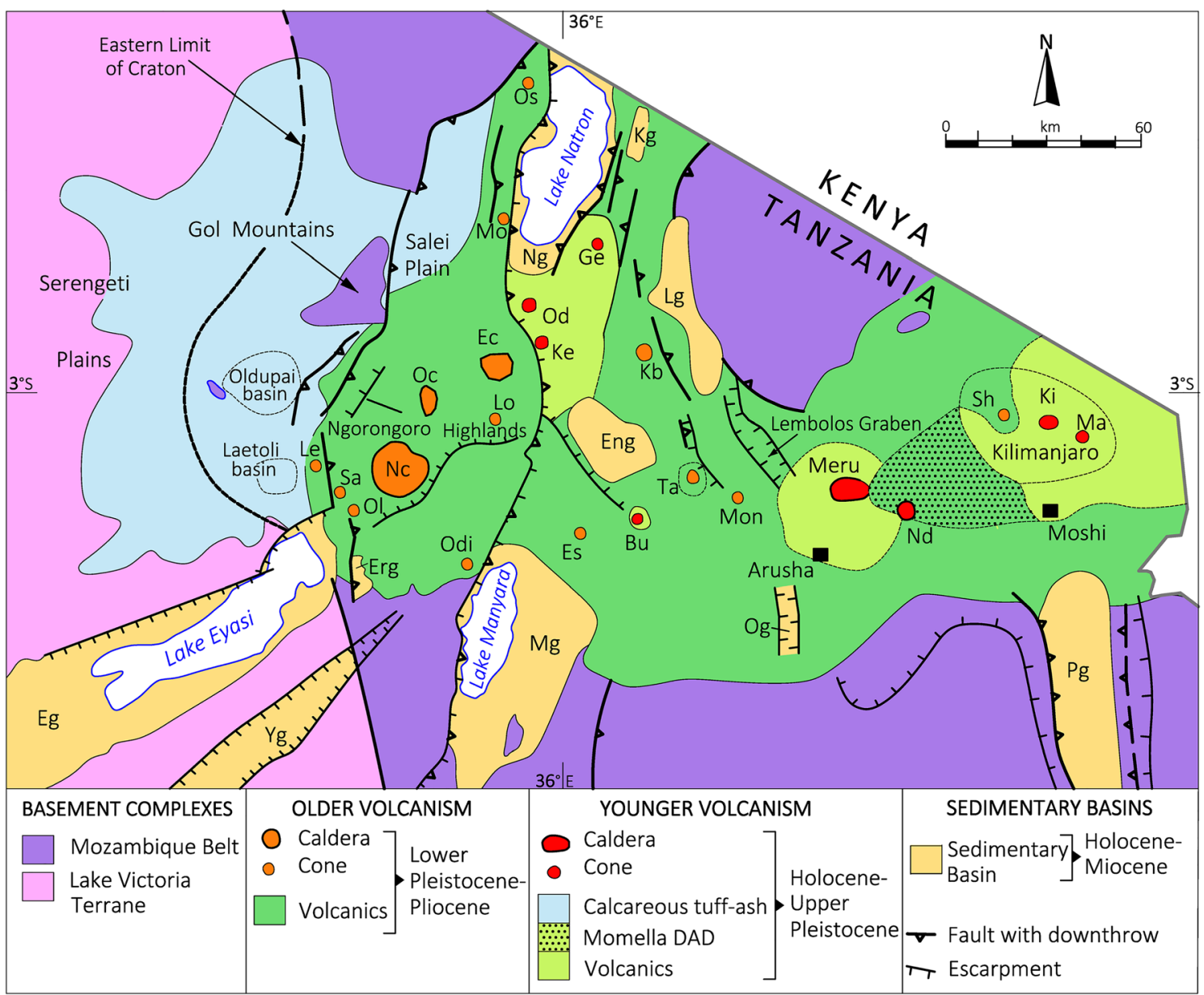

Fig. 7 Geological map of part of northern Tanzania (after Dawson 2008). The Northern Tanzanian Divergence includes the Ngorongoro Volcanic Complex (Ngorongoro Highlands), numerous discrete volocanic cones, two giant volcanic edifices (Meru and Kilimanjaro), and relatively small, sediment-filled grabens. The divergence is comprised of three rifts: the Natron-Manyara Half-graben (centre), the Eyasi Half-graben (west), and the Pangani Graben (east). The half-grabens are characterized by the occurreence of major faults on the western boundaries (faults are generally absent frorm the eastern sides). The dominance of "older" volcanic terrains in the rift system is emphasized and for this reason the calcaerous volcanic ash associated with Oldoinyo Lengai (which covers parts of the eastern Serengeti Plains as a thin skin) has been omitted from the northern part of the Ngorongoro Volcanic Complex, including sections of the Ngorongoro Caldera. Cones: Burko (Bu); Essimingor (Es); Gelai (Ge); Kerimasi (Ke); Kibo (Ki); Ketumbeine (Kb); Lemagrut (Le) or Makarot; Loolmalasin (Lo); Mawenzi (Ma); Monduli (Mon); Mosonik (Mo); Ngurdoto (Nd); Oldeani (Ol); Oldoinyo Dili (Odi); Oldoinyo Lengai (Od); Oldoinyo Sambu (Os); Sadiman (Sa); Shira (Sh); and Tarosera (Ta). Calderas: Empakaai (Ec); Ngorongoro (Nc); and Olmoti $(\mathrm{Oc})$. Sediment-filled grabens: Engaruka (Eng); Erumkoko (Erg); Eyasi (Eg); Lembolos (Lg); Manyara (Mg); Natron (Ng); Oljoro (Og); Pangani (Pg); and Yaida (Yg) similar climatic patterns to those observed today were established (Olago et al. 2009). The icefields and slope glaciers on the main peaks (Mount Kenya, Kibo and Rwenzori) are rapidly shrinking (Hardy 2011; Pepin et al. 2014).

\section{Relationship Between Geological Terrains and Fauna and Flora}

Many volcanic uplands in East Africa supply groundwater to regional plateaus that would otherwise be far too arid to support large herds of grazers. The Kilimanjaro massif is the principal source of groundwater for the Amboseli Plains.
Chyulu Hills is the main catchment (Mzima Springs) for Tsavo West, an area where the site of large herds of grazers on the arid plains was remarked upon by Thomson (1880). Biannual rainy seasons (April-May; September-November) convert the arid eastern Serengeti Plains into lush pastures, triggering one of the world's great migrations. An estimated 1.5 million Wildebeest or White-bearded Gnu (Connochaetes taurinus), 0.5 million Burchell's Zebra (Equus quagga or Equus burchellii), 0.2 million Thomson's gazelle and 18,000 Eland (Taurotragus oryx) are affected. Herds move north during July-August towards the Maasai Mara Reserve and return south and east in September-November. Calving, the most static time for the Wildebeest, occurs during January-March 


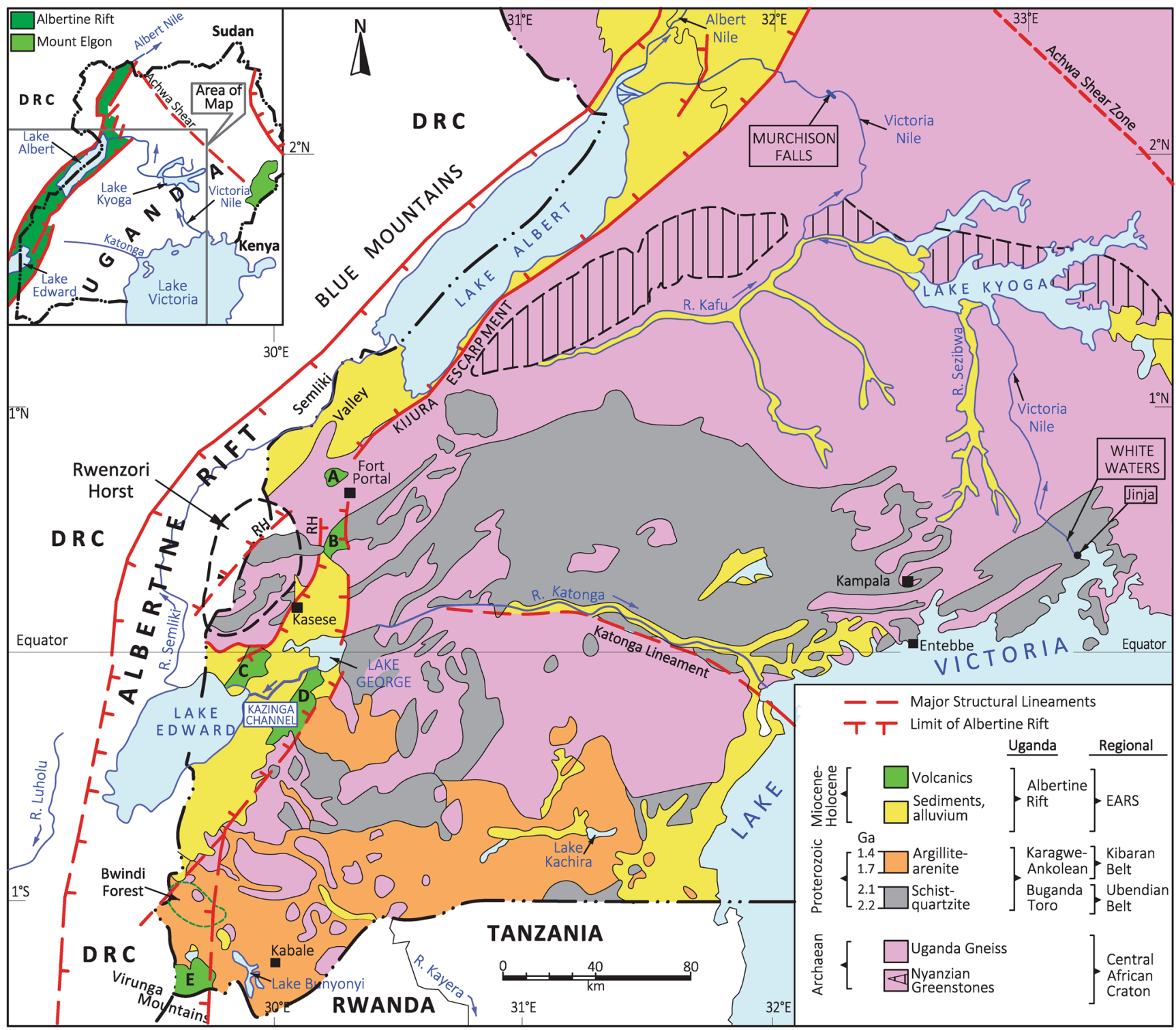

Fig. 8 Geological map of part of Uganda simplified from the 1:1.500, 000 scale map compiled by R. MacDonald and published by the Department of Geological Survey and Mines, Uganda (1966)

in an area where nutrient-rich short grasses grow on calcareous volcanic ashes (Scoon 2018a). The ashes are derived from recent eruptions of the Oldoinyo Lengai Volcano (Dawson 2008). Growth of the short grasses persists for a considerable period due to a relatively shallow water table. The Ngorongoro Caldera reveals a diversity of habitats, including freshwater swamps, alkaline lakes, grassland and forest. In the dry seasons, grazers favour a quadrant where the caldera floor is capped by ash from Oldoinyo Lengai.

Cichlid fish in the African Great Lakes illustrate great diversity, with more than 2000 species occurring just in Lake Victoria (Johnson et al. 1996; Sturmbauer et al. 2011). Speciation is a reaction to a combination of the unusual geology of the region and palaeoclimatic cycles (Danley et al. 2012). A similar hypothesis may be applicable to current populations of some birds and mammals in East Africa. The link with volcanism is pronounced. Lesser Flamingo (Phoeniconaias minor) and Greater Flamingo (Phoenicopterus ruber) concentrate in huge numbers on soda lakes of the Gregory Rift as their filtration systems have evolved to exploit cyanobacteria found in toxic brines (Fig. 15). The occurrence of some species of large grazers, such as Thomson's gazelle and Burchell's Zebra in the Gregory Rift, and their absence from the Albertine Rift, where grazers have a Central or West African provenance, is significant. Afromontane forests of the Aberdare Hills (plateau volcanics) and Mount Kenya (shield volcano) contain endangered species of large mammals, e.g. Bongo (Boocercus eurycerus) and Giant Forest Hog (Hylochoerus meinertzhageni), males of which are unusually dark. Melanistic variants of Leopard 
(a)
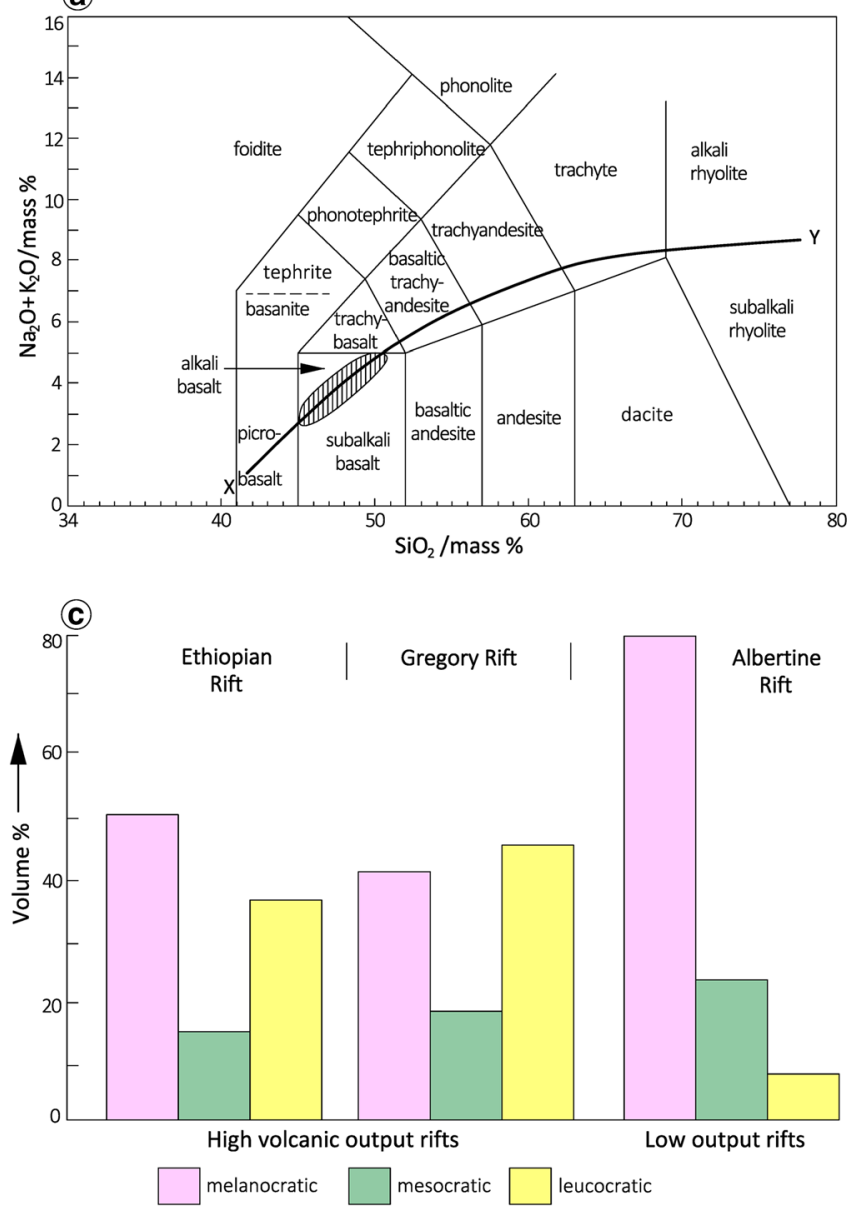

Fig. 9 a The TAS diagram (total alkalis versus silica) discriminates some of the silicate volcanic magmas. The carbonatite magma cannot be plotted on this diagram (an extension of the foidite group). b Lavas from the Gregory Rift, Kenya define three groups (data of Baker 1987); arrows illustrate evolution trends with decreasing age. c Output of the three branches of the EARS expressed by relative proportions of volcanics subdivided by colour index (after Barberi et al. 1982). d Volcanoes that

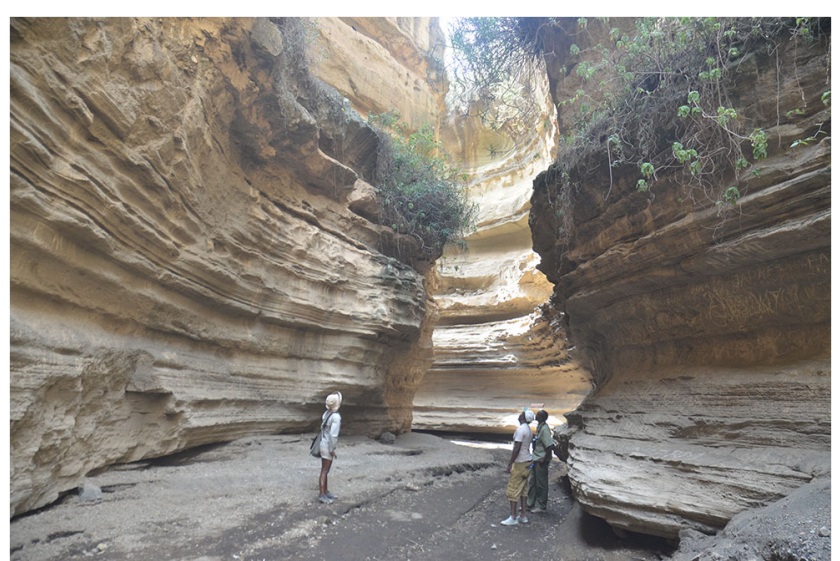

Fig. 10 The near-vertical walls of Njorowa Gorge, Hell's Gate National Park are composed of multiple layers of finely-bedded volcanic ash. The yellow coloration is typical of siliceous rhyolitic compositions associated with highly explosive volcanism which can be extremely hazardous

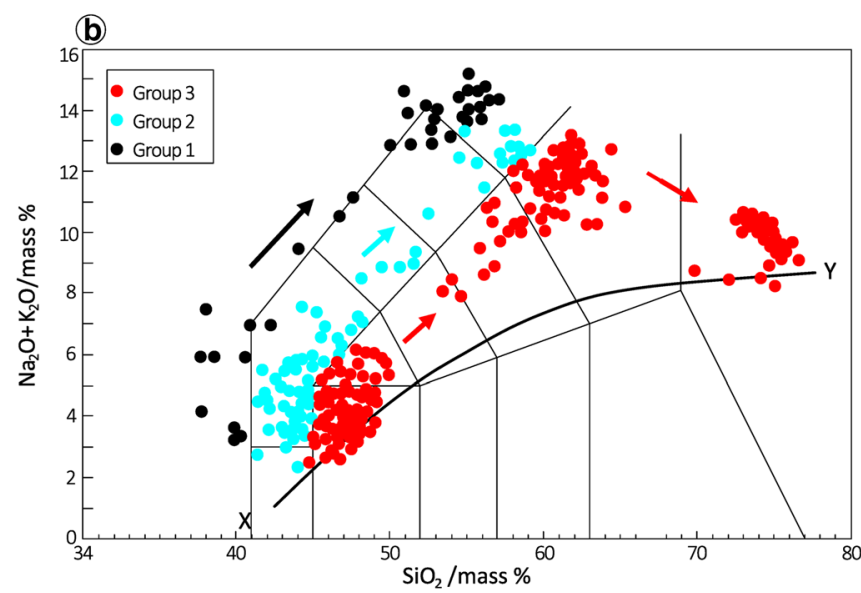

(d)

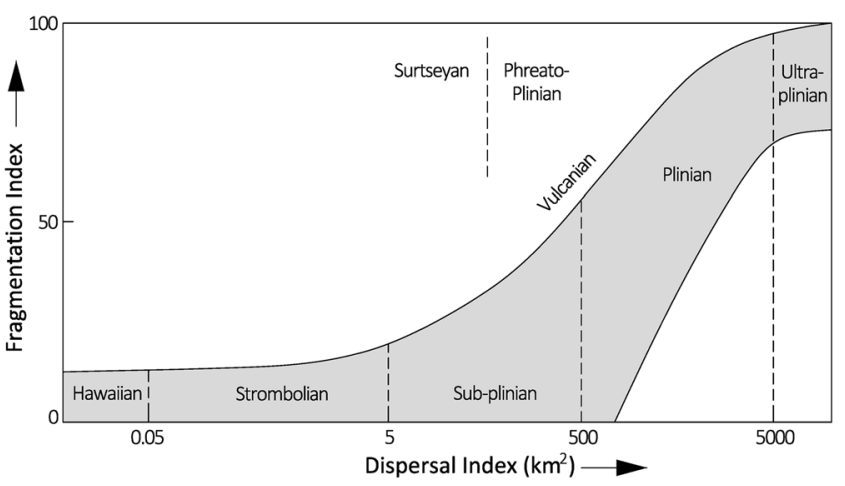

generate pyroclastic fall deposits can be divided into groups based on a plot of fragmentation index (percentage of deposit with grains finer than $1 \mathrm{~mm}$ ) against the area of dispersal (after Walker 1973, and Wright et al. 1980). Many of the volcanoes associated with the Gregory Rift fall within the Sub-plinian and Plinian divisions which are associated with catastrophic eruptions and can disperse ash over huge areas

(Panthera pardus pardus), Serval (Felix serval) and Large Spotted Genet (Genetta tigrina) also occur. The unusual camouflage is a reaction to dense afromontane forests located on alkaline volcanics which produce nutrient-rich soils in the equatorial setting (Gregory 1894).

The Eastern chimpanzee (Pan Troglodyte's schweinfurthii) has been intensively studied in parts of the Albertine Rift, e.g. at Gombe Stream, northern Tanzania and Kibale, Uganda (Fig. 16a). The absence of this species from the Gregory Rift, despite forests offering similar habitats occurring, may be due to climatic change, restricted gene pools or human activity. Opening of grasslands due to climatic change in the PlioPleistocene, when forests that once covered East Africa retreated westward, could be a significant factor in evolution of all East African primates, including hominins (Leakey 1984).

The genus gorilla is thought to have split from other primates in the Miocene (albeit the fossil record in this regard is poor), but separation of Mountain gorilla (Gorilla beringei) 


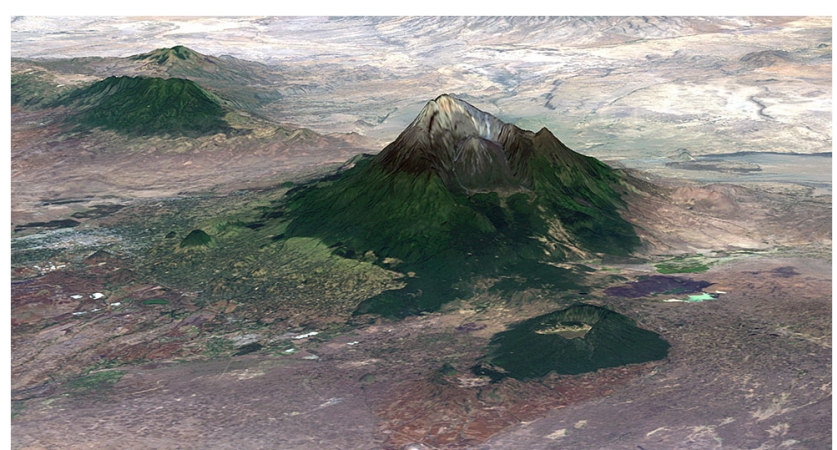

Fig. 11 Three-dimensional satellite image looking northwest over Mount Meru towards the older Monduli and Tarosera volcanoes. Meru includes an annular ring of forest on the lower slopes and a massive, partially collapsed caldera, open to the east, with a central cone of ash and cinder. Little Meru is visible as a small triangular shaped cone on the northeastern slopes. The Ngurdoto Crater occurs in the foreground. The hummocky ground and lakes associated with the Momella debris avalanche deposit occur east of the Meru Caldera and north of the Ngurdoto Crater. Source: NASA Landsat 7 ETM+ image mosaic for the year 2000 from the University of Maryland Global Land Cover Facility overlaid on elevation data from the Shuttle Radar Topography Mission, courtesy of Philip Eales, Planetary Visions

(Fig. 16b) from Western and Eastern Lowland gorilla (Gorilla gorilla) is estimated to have occurred at $0.4 \mathrm{Ma}$ (Stanford 2001). Mountain gorilla is restricted to only two populations, Bwindi and the Virunga (Fig. 14). The geological evidence suggests that the Mountain gorilla in Bwindi (Uganda) is liable to be the oldest. The Bwindi Impenetrable Forest occurs on basement rocks (Kibaran Belt), part of the Kigezi Highlands, which were uplifted during the Pliocene (Fig. 14). The afromontane forests here are relatively old and contain a tremendous diversity of species. The population of
Mountain gorilla in the afromontane forests on the slopes of the Virunga Mountains (DRC, Rwanda and Uganda) is liable to be considerably younger. The forests here are relatively youthful as they grow on volcanic cones which are Late Pleistocene and Holocene features.

\section{Geotourism}

All of the national parks referred to here have potential for geotourism, independent of the necessity of establishing geoparks (Fig. 2). Organized safaris starting at international airports can be tailored to individual groups and most operators can adapt wildlife tours to include the principal geosites. The region is relatively safe for tourism, although the hazardous nature of some of the volcanoes requires monitoring. Potential advantages of geotourism, over and above marketing to additional interest groups and the requirement of locally trained specialized guides, is that the tours can be directed at the low seasons for wildlife tourism. Many of the geosites offer excellent opportunities for teaching purposes where the relationship with fauna and flora can be emphasized. Some geotourism opportunities are outlined below. Geological maps and descriptions of geosites in parks of southern Uganda (Scoon 2017, 2018b) and central/southern Kenya and northern Tanzania (Scoon 2018a) may assist self-guided tours.

Visits to examine the geological features of the national parks in central/southern Kenya generally commence from Nairobi (Fig. 6). Tours can be organized to combine national parks in specific regions. The Amboseli and Tsavo West National Parks
Fig. 12 a Mount Nyiragongo (DRC) includes an active crater which in March 2020 contained a lava lake (left) and a new vent (right), the latter revealing lava fountains which attain a height of approximately $50 \mathrm{~m}$. b The rim of the crater is formed of lava related to the major eruption of 1977; the steep walls are built of nearhorizontal layers of lava and volcanic tephra associated with older eruptions. $\mathbf{c}$ The lava lake and active vent are a spectacular sight in the twilight. d A night-time view of the lava lake shows the occurrence of cracks and segments with magma flares
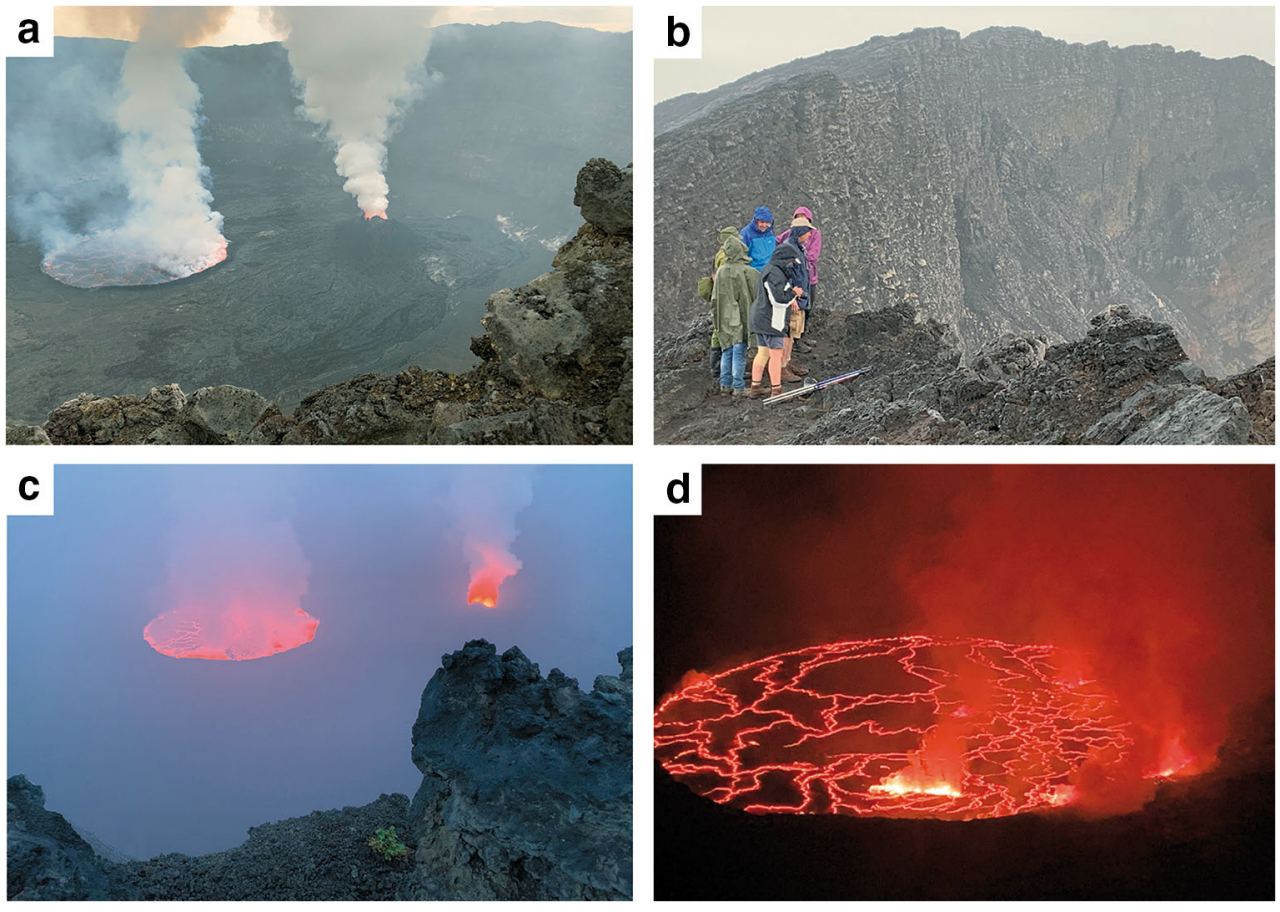


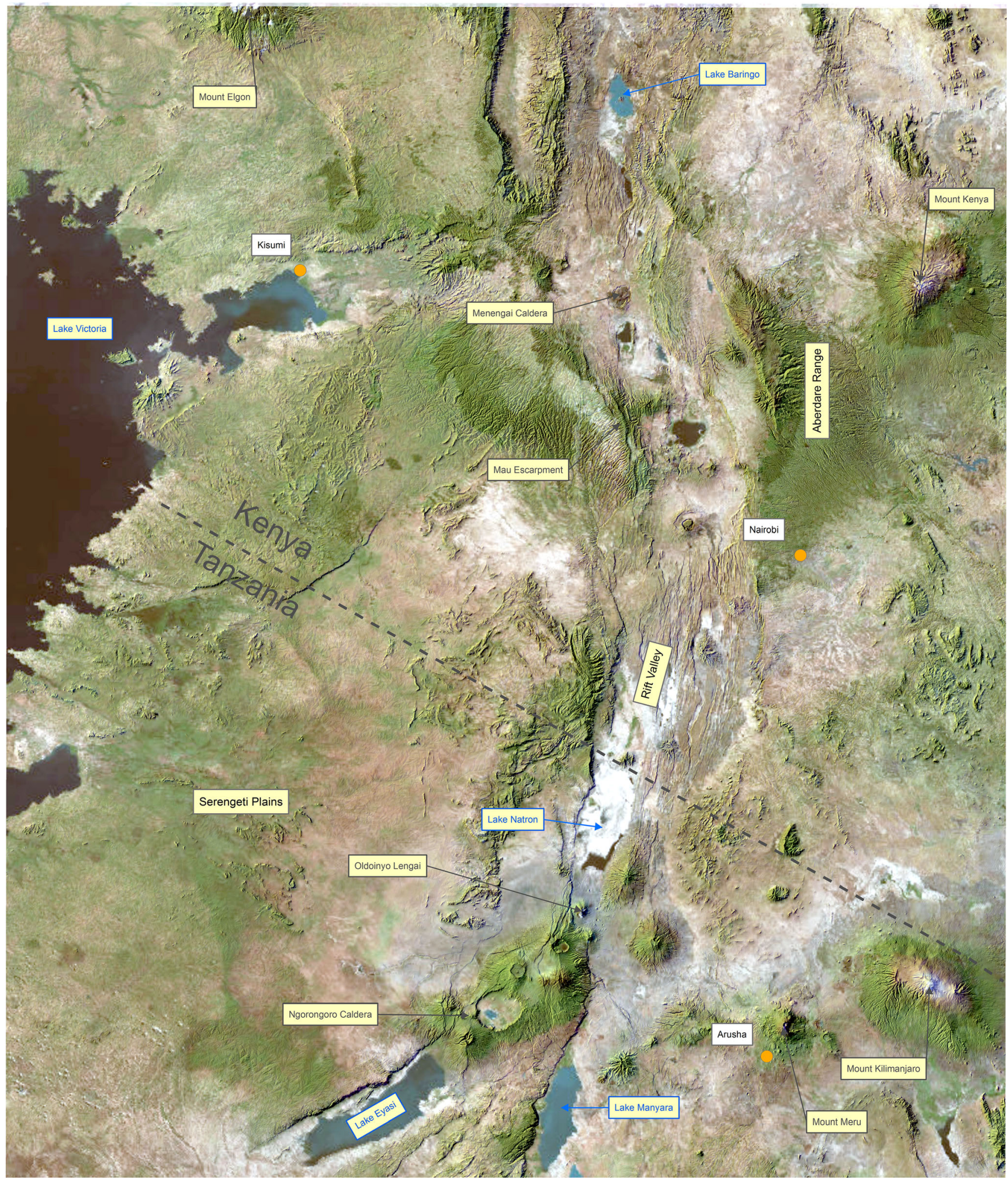

Fig. 13 A digital terrain image of part of the Gregory Rift in southern Kenya and northern Tanzania reveals the principal ecosystems, such as regional plateaus, escarpments, ribbon-shaped lakes and volcanic cones. The occurrence of calderas in the rift valley and giant volcanic edifices on rift shoulders are characteristic of this rift. Source: Cloud-free composite image based on Terra-MODIS satellite images of NASA courtesy of Philip Eales (Planetary Visions), with digital terrane shading created using ArcGIS $\circledR_{\text {software by Esri by Oliver Burdekin (BurdGIS) }}$ 

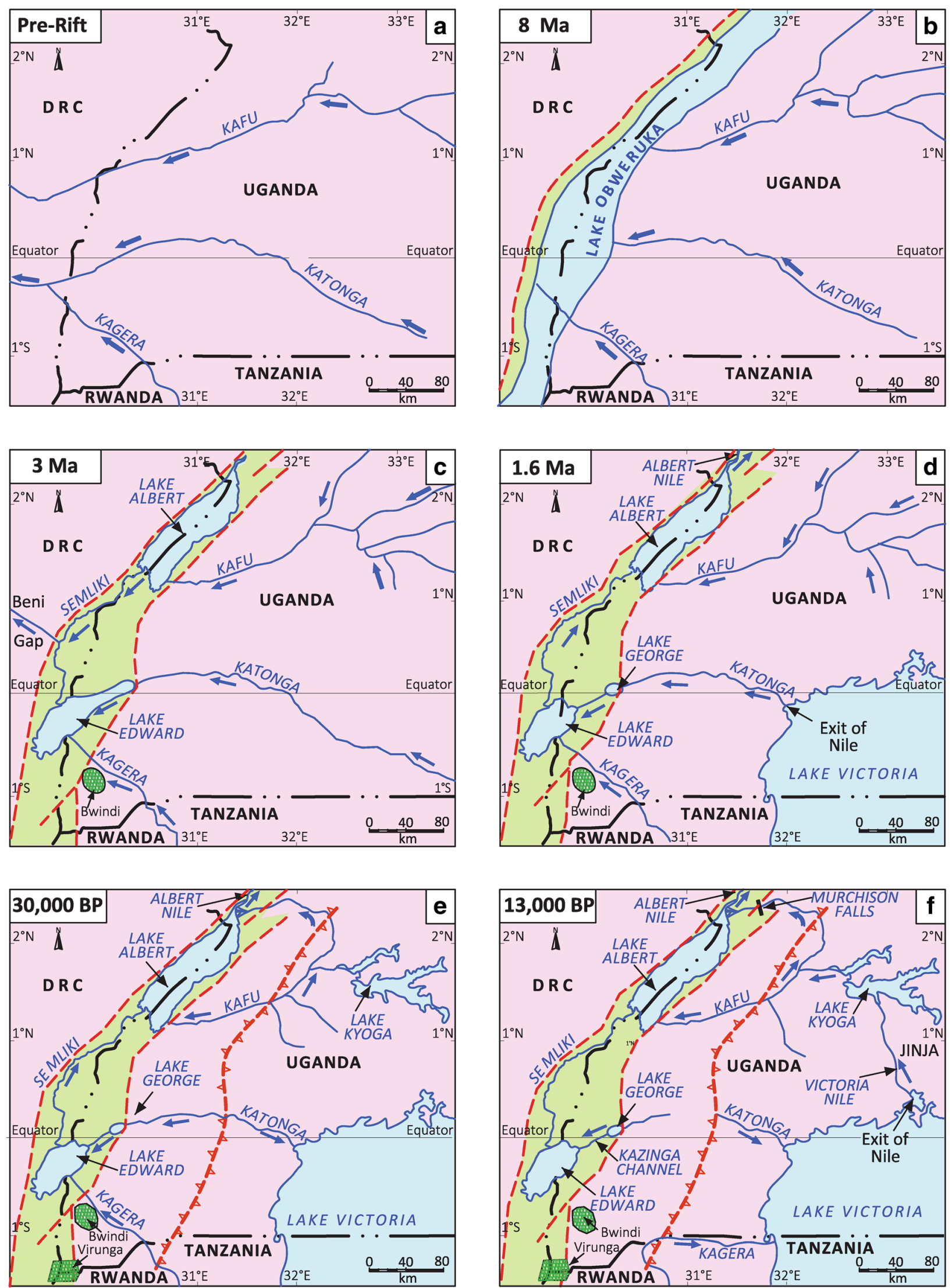

Basement -- Albertine Rift $\quad \wedge \wedge$ Trend of Uplift between 
4 Fig. 14 Schematic showing development of the Albertine Rift, Lake Victoria and the Victoria Nile in stages as follows: a pre-rifting; $\mathbf{b}$ formation of the giant palaeo-lake, Lake Obweruka; $\mathbf{c}$ the opening of the Beni Gap; d formation of Lake Victoria, uplift of the Kigezi Highlands and closure of the Beni Gap; e upwarping west of Lake Victoria and the Virunga volcanism; and $\mathbf{f}$ formation of the Victoria Nile, a new outlet of Lake Victoria

include the opportunity to walk on recent, unvegetated lava flows, examine cinder cones, an extinct lava tube and parasitic volcanic cones at the base of the Kilimanjaro edifice. The influence of the volcanic uplands on control of groundwater movements and formation of swamps is a notable feature of these parks. Visits to the Gregory Rift can combine the Hells Gate, Longonot, Lake Baringo and Lake Bogoria National Parks and Reserves where the combination of volcanic landforms and alkaline lakes can be observed. Lake Bogoria includes active geothermal features. A visit to the Aberdare and Mount Kenya National Parks provides the opportunity to compare the landforms associated with plateau-style outpourings and a central conduit-style eruption.

The Ngorongoro-Lengai Geopark in northern Tanzania is generally accessed from Arusha (Fig. 7). Localities of interest here include the Ngorongoro Caldera, the extinct volcanic cones and calderas in the Ngorongoro Highlands, the active volcano of Oldoinyo Lengai and the toxic salts at Lake Natron. Safaris to this region can include the adjoining Lake Manyara and Serengeti National Parks. Arusha also serves the Kilimanjaro and Arusha National Parks, primarily known for mountain hikes. There are currently no dedicated geotours, but most safaris include visits to the important geosites. The volcanic ash deposits of Mount Meru, the debris avalanche deposit hosting the Momella Lakes and the spectacular caldera with its huge cliff faces are highlights of the Arusha National Park. The ascent of Kilimanjaro could be tailored to include glacial moraines and icefields where the impact of the Late Pleistocene glaciations and Holocene climatic changes can be observed.

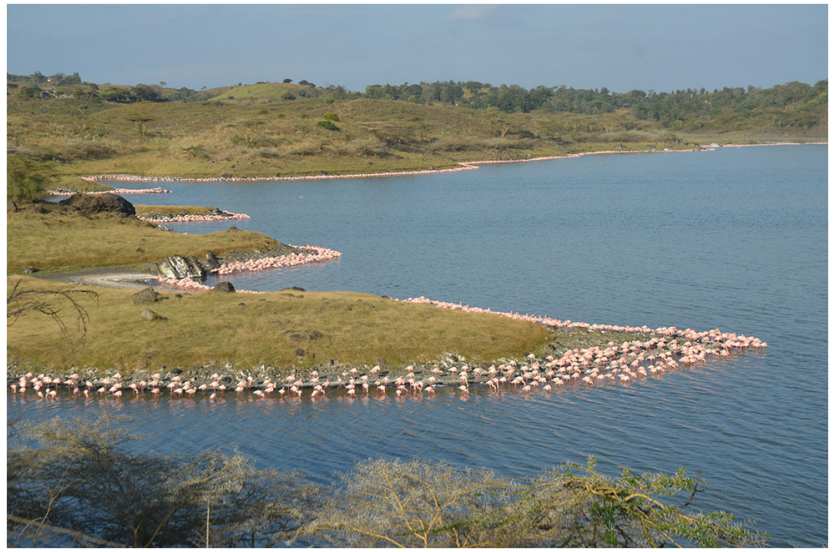

Fig. 15 Greater and Lesser Flamingo fringe Big Momella Lake which has developed in the Arusha National Park at the base of Mount Meru in hummocky ground associated with a debris avalanche deposit
Visits to examine the geological features of the national parks in southern Uganda generally commence from Entebbe (Fig. 8). Tours can be organized to observe rivers captured by the Albertine Rift. The most interesting example is the Victoria Nile and Murchison Falls. The Murchison Falls and Queen Elizabeth National Parks protect extensive grassy and wooded savannahs located within the Albertine Rift. The latter two parks border Lake Albert and Lake Edward, respectively, relatively large lakes typical of this branch of the rift valley. The Rwenzori Mountains and Semliki National Parks contain a diversity of ecosystems including alpine heathland and afromontane and tropical forests. Kibale National Park protects a forested area on the shoulders of the Albertine Rift known for studies on habituated groups of chimpanzee. The Lake Mburo National Park occurs on the regional plateau in an area of grassy savannah with swamps and small lakes associated with rift-related warps.

Treks to observe the Mountain gorilla can be undertaken in southern Uganda (Bwindi Impenetrable Forest and Mgahinga Gorilla National Parks), Rwanda (Volcanoes National Park)
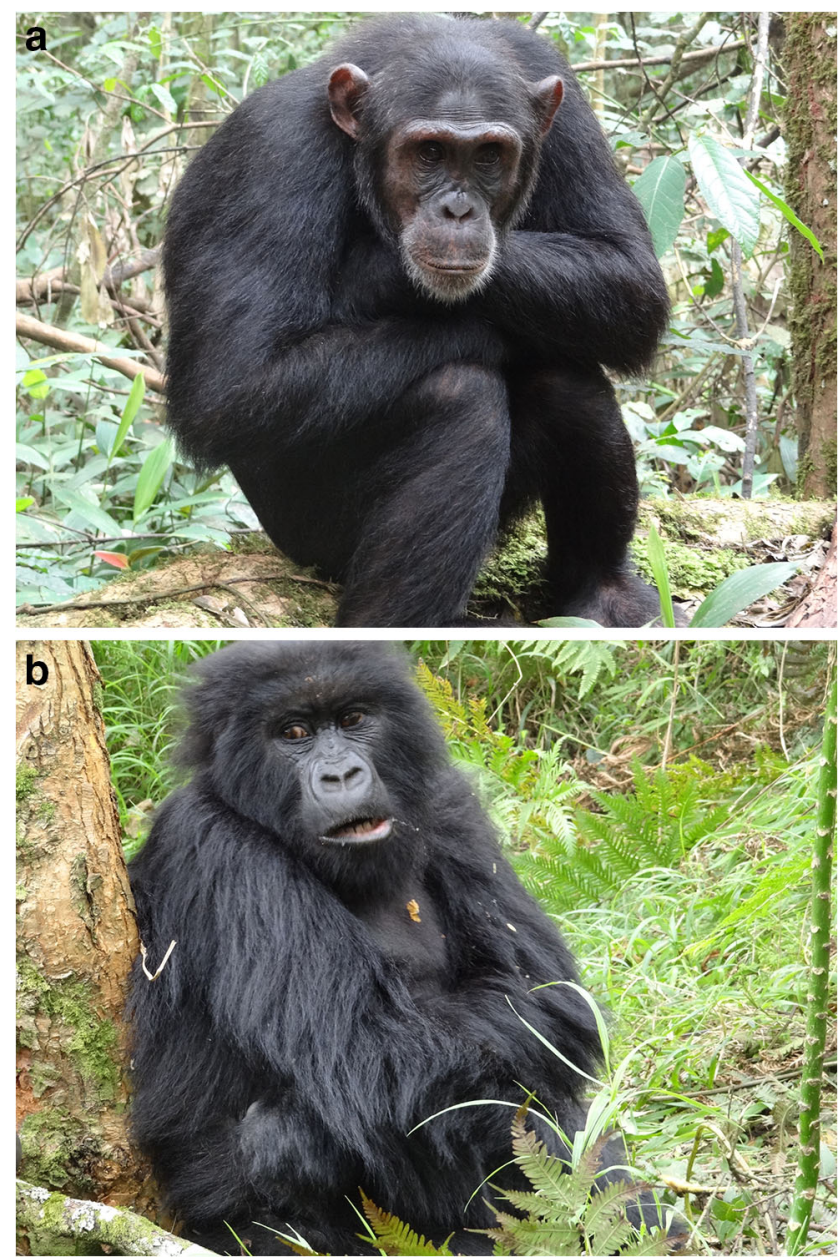

Fig. 16 a Chimpanzee is protected in the Kibale Forest National Park. b Mountain gorilla in the Virunga Mountains, Rwanda, may be a younger population as compared with Bwindi, Uganda 
and the DRC (Virunga National Park). Each park includes extensive afromontane forests with habituated groups of Mountain gorilla. Tours to Rwanda usually commence in Kigali and can be combined with a visit to the DRC. The opportunity to ascend the active Nyiragongo Volcano is a highlight of a visit to the Virunga National Park. Tour groups are guided to the summit where mountain huts have been constructed on the rim of the crater. The proximity of the huts to the active crater enables night-time views of the glowing lava lake (Fig. 12c, d). The Virunga National Park contains the greatest diversity of fauna and flora in Africa.

\section{Conclusions}

Rapid and diverse speciation in East Africa during the past thirty million years is primarily a reaction to the unusual geology and palaeo-climatic cycles. The widespread fall-out of radioactive volcanic ash could have increased the occurrence of mutations (Ebisuzaki and Maruyama 2015). As rifting and volcanism persisted, an increasing number of geological terrains formed, many of which were isolated by the regional plateaus. This triggered island-style speciation patterns, despite the continental setting. During the Plio-Pleistocene when hominins roamed large parts of East Africa, with migration enforced by annual rainfall patterns, as with grazers on the Serengeti Plains, evolution may in part have been a reaction to cataclysmic volcanism. East Africa is one of the few areas where recent evolutionary patterns (specifically including primates and hominins) can be investigated. The identification of discrete areas underlain by volcanic ashes associated with recent eruptions of Oldoinyo Lengai is possibly the most intriguing example. The presence of potentially hazardous volcanoes which may experience explosive, Plinianstyle eruptions in the future should be closely monitored. Visits to the national parks offer the opportunity to examine the close relationship between geology and fauna and flora. The potential to establish specialized geotours and additional geoparks should be encouraged.

Acknowledgements Maps and diagrams were drafted by Lyn Whitfield and satellite images processed by Philip Eales of Planetary Visions and Oliver Burdekin of BurdGIS.

Open Access This article is licensed under a Creative Commons Attribution 4.0 International License, which permits use, sharing, adaptation, distribution and reproduction in any medium or format, as long as you give appropriate credit to the original author(s) and the source, provide a link to the Creative Commons licence, and indicate if changes were made. The images or other third party material in this article are included in the article's Creative Commons licence, unless indicated otherwise in a credit line to the material. If material is not included in the article's Creative Commons licence and your intended use is not permitted by statutory regulation or exceeds the permitted use, you will need to obtain permission directly from the copyright holder. To view a copy of this licence, visit http://creativecommons.org/licenses/by/4.0/.

\section{References}

Bailey DK (1974) Continental rifting and alkaline magmatism. In: Sorensen H (ed) The alkaline rocks. Wiley, pp 148-159

Baker BH (1987) Outline of the petrology of the Kenyan rift alkaline province. In: Fitton JG, Upton BGJ (eds) Alkaline igneous rocks, vol 30. Geological Society of London special publication, pp 293 311

Baker BH, Mohr PA, Williams LAJ (1972) Geology of the Eastern Rift System of Africa. Geological Society of America Special Paper 136, $67 \mathrm{p}$

Baker BH, Wohlenberg J (1971) Structure and evolution of the Kenyan Rift Valley. Nature 229:538-542

Barberi F, Santacroe R, Varet J (1982) Chemical aspects of rift magmatism. In: Palmason G (ed) Continental and oceanic rifts: final report of inter-union commission on geodynamics workshop group 4, "continental and oceanic rifts", vol 8. American Geophysical Union, geodynamics series, Washington, pp 223-258

Beadle LC (1981) The inland waters of tropical Africa-an introduction to tropical limnology, 2nd edn. Longman, London $475 \mathrm{p}$

Begg GC, Griffin WL, Natapov LM, O’Reilly SY, Grand SP, O’Neill CJ, Hronsky JMA, Poudjom-Djomani Y, Swain CJ, Deen T, Bowden P (2009) The lithospheric architecture of Africa: seismic tomography, mantle petrology, and tectonic evolution. Geoscience 5:23-50

Blumenschine RJ, Stanistreet IG, Njau JK, Bamford MD, Masao FS, Albert RM, Stollhofen H, Andrews P, Prassack KA, McHenry LJ, Fernandez-Jalvo Y, Camilli EL, Ebert JI (2012) Environments and hominin activities across the FLK peninsula during Zinjanthropus times (1.84 ma), Olduvai Gorge, Tanzania. J Hum Evol 63:364-383

Cerling TE, Wynn JG, Andanje SA (2011) Woody cover and hominin environments in the past 6-million years. Nature 476(7358):51-56

Chorowicz J (2005) The East African Rift system. J Afr Earth Sci 43: $379-410$

Danley PD, Husemann M, Ding B, DiPietro LM, Beverly EJ, Peppe DJ (2012) The impact of the geologic history and paleoclimate on the diversification of East African cichlids. Int J Evol Biol Article ID $574851,20 \mathrm{p}$

Dawson JB (2008) The Gregory Rift Valley and Neogene-recent volcanoes of northern Tanzania. Geol Soc Memoir 33, 102 p, 3, 7

Dawson JB, Mitchell RH (2008) Oldoinyo Lengai. Contribution to Bulletin of the Global Volcanism Network 32:14-15

Dawson JB, Pinkerton H, Norton GE, Pyle DM, Browning P, Jackson D, Fallick AE (1995) Petrology and geochemistry of Oldoinyo Lengai lavas extruded in November 1988: magma source, ascent, and crystallization. In: Bell K, Keller J (eds) Carbonatite volcanism. Springer, Berlin, pp 47-69

Deino AL (2012) Ar/ Ar dating of bed I Olduvai Gorge, Tanzania and the chronology of early Pleistocene climate change. In: Blumenschine RJ, Masao ET, Stanistreet IG, Swisher CC (eds) Five decades after Zinjanthropus and Homo habilis: landscape paleoanthropology of Plio-Pleistocene Olduvai Gorge, Tanzania. Journal of human evolution, vol 63, pp 252-273

Delcamp A, Delvaux D, Kwelwa S, Macheyeki A, Kervyn M (2015) Sector collapse events at volcanoes in the north Tanzanian divergence zone and their implications for regional tectonics. Geol Soc Am Bull 128:169-186

Demencal PB (2004) African climate change and faunal evolution during the Pliocene-Pleistocene. Earth Planet Sci Lett 220(1-2):3-24

Dirks PHGM, Blenkinsop TG, Jelsma HA (2015) The geological evolution of Africa. In: geology volume IV, Encyclopaedia of Life Support Systems (EOLSS)

Downie C, Wilkinson WH (1972) Geology of Kilimanjaro. Joint University of Sheffield-Tanzania Geological Survey Expedition, $253 \mathrm{p}$ 
Ebinger C (2005) Continental break-up: the East African perspective. Astron Geophys 46(2):16-21

Ebinger C, Poudjom-Djomani Y, Mbede E, Foster A, Dawson JB (1997) Rifting Archaean lithosphere: the Eyasi-Natron rifts, East Africa. J Geol Soc Lond 154:947-960

Ebinger CJ, Yemane T, Harding DJ, Tesfaye S, Kelley S, Rex DC (2000) Rift deflection, migration, and propagation: linkage of the Ethiopian and eastern rifts, Africa. Geol Soc Am Bull 112:163-176

Ebisuzaki T, Maruyama S (2015) United theory of biological evolution: disaster-forced evolution through supernova, radioactive ash fallouts, genome instability, and mass extinctions. Geosci Front 6: $103-119$

Eugster HP (1980) Lake Magadi, Kenya and its Pleistocene precursors. In: Nissenbaum A (ed) Hypersaline brines and evaporitic environments. Elsevier, Amsterdam, pp 195-232

Gregory JW (1894) Some factors that have influenced zoological distribution in Africa. Proc Zool Soc London:165-166

Gregory JW (1896) The great Rift Valley. John Murray, London

Hardy DR (2011) Kilimanjaro. In: Singh VP, Singh P, Haritashya UM (eds) Encyclopaedia of snow, ice and glaciers, Encyclopaedia of Earth Sciences Series. Springer, pp 672-679

Hay RL (1976) Geology of the Olduvai Gorge: a study of sedimentation in a Semiarid Basin. University of California Press, Berkeley, 203 p

Johnson TC, Scholz CA, Talbot MR (1996) Late Pleistocene desiccation of Lake Victoria and rapid evolution of cichlid fishes. Science 273(5278):1091-1093

Leakey MD (1981) Discoveries at Laetoli in northern Tanzania. Proc Geol Assoc 92(2):81-86

Leakey MD (1984) Disclosing the past. Doubleday and Co., New York

Le Gall B, Nonnotte P, Rolet J, Benoit M, Guillou H, Mousseau-Nonotte M, Albaric J, Deverchere J (2008) Rift propagation at craton margin: distribution of faulting and volcanism in the north Tanzanian divergence (East Africa) during Neogene times. Tectonophysics 448:119

Maasha N (1975) The seismicity and tectonics of Uganda. Tectonophysics 27:381-393

McHenry LJ, Mollel GF, Swisher CC (2008) Compositional and textural correlations between Olduvai Gorge bed I tephra and volcanic sources in the Ngorongoro volcanic highlands, Tanzania. Quat Int 178:306-319

McKenzie D (1978) Some remarks on the development of sedimentary basins. Earth Planet Sci Lett 40:25-32

Merle G (2011) A simple continental rift classification. Tectonophysics 513:88-95

Mollel GF, Swisher CC, Feigenson MD, Carr MJ (2008) Geochemical evolution of Ngorongoro Caldera, Northern Tanzania: implications for crust-magma interaction. Earth Planet Sci Lett 271:337-347

Nicholson SE (1996a) A review of climate dynamics and climate variability in Eastern Africa. In: Johnson TC, Odada EO (eds) The limnology, climatology and paleoclimatology of the East Africa Lakes, Gordon and Breach Amsterdam, pp 25-56

Nicholson SE (1996b) Sedimentary processes and signals of past climatic changes in the large lakes of the African Rift Valley. In: Johnson TC, Odada EO (eds) The limnology, climatology and paleoclimatology of the East Africa Lakes, Gordon and Breach Amsterdam, pp $367-412$

Nusbaum RL, Girdler RW, Heirtzler JR, Hutt DJ, Green D, Millings VE, Schmoll BS, Shapiro J (1993) The distribution of earthquakes and volcanoes along the East African Rift system. Episodes 16(4): $16427-16432$

Olago D, Opere A, Barongo J (2009) Holocene palaeohydrology, groundwater and climate change in the lake basins of the Central Kenya Rift. Hydrol Sci J 54(4):765-780

Osmaston H (2004) Quaternary glaciations in the East Africa Mountains. In: Ehlers J, Gibbard PI (eds) Developments in quaternary sciences, quaternary glaciations extent and chronology part III: South
America, Asia, Africa. Australasia, Antarctica, 2C, Amsterdam, Elsevier, pp 139-150

Pepin NC, Duane WJ, Schaefert M, Pike G, Hardy D (2014) Measuring and remodelling the retreat of the summit icefields on Kilimanjaro, East Africa. Arct Antarct Alp Res 46:905-917

Saggerson EP, Baker BH (1965) Post-Jurassic erosion surfaces of East Africa and their deformation in relation to rift structure. J Geol Soc Lond 121:51.72

Sarie E, Calais E, Stamps DS, Delvaux D, Hartnady C (2014) Present day kinematics of the East African Rift system. J Geophys Res 119: 3584-3600

Scoon RN (2017) Geotraveller 31: The Victoria Nile, Murchison Falls and Lake Albert, Uganda. Geobulletin 60(3):26-33 https://doi.org/ 10.13140/RG.2.2.32836.32649

Scoon RN (2018a) Geology of National Parks of central/southern Kenya and northern Tanzania. Springer International, $220 \mathrm{p}$

Scoon RN (2018b) Geotraveller 34: Geology of National Parks of southwestern Uganda. Geobulletin 61(2):36-42. https://doi.org/10. 13140/RG.2.2.10564.07049

Scott SC (1980) The geology of Longonot volcano, Central Kenya: a question of volumes. Philos Trans R Soc Lond A296:437-465

Simonetti A, Bell K (1995) Nd, Pb, and Sr isotopic data from the Mount Elgon volcano, eastern Uganda - western Kenya: implications for the origin and evolution of nephelinite lavas. Lithos 36:141-153

Stanford C (2001) The subspecies concept in primatology: the case of mountain gorillas. Primates 42(4):309-318

Sturmbauer C, Husemann M, Danley PD (2011) Explosive speciation and adaptive radiation of East African cichlid fishes. In: Zachos FE, Habel JC (eds) Biodiversity hotspots-distribution and protection of conservation priority areas. Springer, pp 333-362

Suess E (1885-1901) The face of the Earth (translated by Sollas \& Sollas), vol 3. Clarendon press, Oxford

Tedesco D, Vaselli O, Papale P, Carn SA, Voltaggio M, Sawyer GM, Durieux J, Kasereka M, Tassi F (2007) January 2002 volcano-tectonic eruption of Nyiragongo volcano, Democratic Republic of Congo. J Geophys Res 112:B09202. https://doi.org/10.1029/ 2006JB004762

Talbot MR, Williams MAJ (2008) Cenozoic evolution of the Nile Basin. In: Dumont HJ (ed) The Nile: Origin, Environment, Limnology and Human Use. Springer science-business media B.V., pp 37-60

Thompson LG, Mosley-Thompson E, Davis ME, Henderson KA, Brecher HH, Zagorodnov VS, Mashiotta TA, Lin P-N, Mikhalenko VN, Hardy DR, Beer J (2002) Kilimanjaro ice core records: evidence of Holocene climate change in tropical Africa. Science 298:589-593

Thomson J (1880) Notes on the geology of East-Central Africa. Nature 28:102-104

Walker GPL (1973) Explosive volcanic eruptions - a new classification scheme. Geol Rundsch 62:431-446

Wauthier C, Cayol V, Kervyn F, d'Oreye N (2012) Magma sources involved in the 2002 Nyiragongo eruption, as inferred from an InSAR analysis. J Geophys Res 117. https://doi.org/10.1029/ 2011JB008257

Williams JG, Arlott N, Fennessy R (1994) Collins field guide National Parks of East Africa. Harper Collins Hong Kong, 336 p

Wilson JT (1973) Continental drift, transcurrent and transform faulting. In: Maxwell AE (ed) The sea, vol 4. Wiley, New York, pp 623-644

Windley B (1977) The evolving continents. Wiley and Sons, 399 p

Woolley A (2001) Alkaline rocks and carbonatites of the world. Part 3: Africa. Geological Society of London, $372 \mathrm{p}$

Wright JV, Smith AL, Self S (1980) A working terminology of pyroclastic deposits. J Volcanol Geotherm Res 8:315-336

Zaitsev AN, Wenzel T, Spratt J, Williams TC, Strekopytov S, Sharygin VV, Petrov SV, Golovina TA, Zaitseva EO, Markl G (2011) Was Sadiman volcano a source for the Laetoli footprint tuff? J Hum Evol 61(1):121-124 